\title{
SCHOOL CULTURE, AS AN ORGANISATIONAL CULTURE: THE VALUE ASPECT
}

\author{
Asta Meškauskienė \\ Institute of Educational Sciences, Vilnius University (Lithuania)
}

\begin{abstract}
Organisational culture is a complex, multi - dimensional phenomenon, which recently is widely analysed and discussed by many researchers. This paper aims at analysis of only one aspect of organisational culture of a contemporary school, the values. Today politicians vision Lithuanian school as a learning organisation. It is obvious that it is in the school, where value formation and education of future members of society begin, where actually the axis of the future society is formed. In this research the value system of the school, as learning organisation, is understood as a pluralistic whole, which on the one hand, allows the development and co-existence of contradicting and competing values. On the other hand, the value aspect is an important variable that influences the behaviour and performance of people in the organisation. Common values shared by members of the same organisational culture lead to successful and effectively working school development. The purpose of a multiple case study was to explore social factors of school organisational culture and a value system of investigated school organisational culture, measuring teacher and student attitudes towards it. The main methodological approach: organisation culture is a pluralistic entirety that allows for existence of even contradictory or competing with each other values. This is an open whole, which encourages growth, education and improvement. The methods of the research: Theoretical: analysis and interpretation of scientific sources. Attempts are made to reveal the concept of organisation culture, to characterise school culture, to overview features of school as an organisation; Empirical: questionnaire survey of teachers and learners.
\end{abstract}

Keywords: School culture, fundamental values, shared values.

\section{Introduction}

The beginning of the 21st century has marked the formation of the society, where the continuously changing knowledge has become the most important wealth of its organisations, without which the performance and operation of these organisations cannot be effective (Poškienè, 1998). The organisations striving to unite the professionals for common activities have to give the greatest attention to the social aspects of organisation culture, particularly to the values, the most apparent but not always visible manifestations of organisational culture, and to the common value orientation of both, the individuals and groups, members of the same organisational culture (Poškienè, 1998; Jucevičiené, Poškienè, Kudirkaitè et al., 2000, Robbins, 2006).

For many decades the organisational culture of schools has become the main focus and object of educational research. For contemporary schools as learning organisations play a vital role in education of the future members of society and development of values which in their turn would promote the active development of the learning or knowledge society. According to Simonaitiene (2007), the very idea of the school as a learning organisation is manifest in its main function and the goal.

Every organisation, including school, has a culture. But sometimes it is fragmented, balkanized and difficult to perceive. It may be not clear to outsiders and insiders alike. In order for the school to become an effectively working organisation, it has to develop an organisational culture, which would create favourable conditions, the environment and a value system necessary for knitting together the school community in which students, teachers and school leaders have their own value systems.

\section{Methodology}

The analysis of the values of school organisational culture is based on Schein's (1992) and Simonaitienè's (2007) defined concepts and parameters of organisational culture, which in this research is understood as a pluralistic whole, allowing the co-existence of contradicting and competing values in the 
organisational culture. Such a school culture is perceived as an open system, promoting the development, learning and improvement of organisation and its people. The process of perception and acknowledgement of school culture values has to be consistent with the values of the members of organisation and to lead to acceptance and sharing of the commonly acceptable values (Kavolis, 1996).

The purpose of a multiple case study was to explore social factors of school organisational culture and a value system of investigated school organisational culture, measuring teacher and student attitudes towards it.

The empirical data of a quantitative study analysed in this paper were collected through the employment of a survey method. There were structured surveys conducted in 4 Lithuanian (2 lower secondary and 2 upper secondary/gymnasia) schools. Random research sampling included 54 teachers and 160 students randomly selected from these schools $(\mathrm{N}=214)$. In order to analyse the views of teachers and students on the values manifesting in their school cultures, there were two questionnaires (one for teachers and the other for students) designed.

There was the following hypothesis stated: Most members (teachers and students) of the school culture will mark the common humanistic values as the most important in their school organisation cultures.

After the statistical analysis of collected data was performed, the further analysis was conducted by comparing the data of teacher and student groups belonging to different types of secondary schools.

\section{Theoretical background}

Every organisation is unique in its own way, when trying to achieve its objectives and when trying to resolve the problems it is facing. No matter, if the organisational decisions are made by school leadership alone or by all the members of school community, in all the cases these decisions are influenced by the guiding philosophy and the existing value system of the organisational culture (Vasiliauskas, 2004; Coleman, Earley, 2005). Palidauskaite (2001) stresses that the culture of a particular organisation may be inferred by different things held in common. The existence of commonly shared attitudes, feelings, beliefs, norms of behaviour, ways of thinking and particularly the values of individuals, consistent with those of the organisation, lead to successful achievement of all the objectives, the improvement of interpersonal cooperation and the advancement of organisation. Though many authors speak of the pluralism of contemporary society, they do agree that organisational culture has a vital role and influences the quality of the professional life at a national level and at the level of organisation (McLaughlin, 1997; Hofstede, 2001).

The concept of values related to organisational culture as well as the concept of organisational culture itself has many definitions and interpretations. None of them are exhaustive and can define all the aspects of this very complicated phenomenon (Jovaiša, 2003; Jucevičienè, Poškienė, Kudirkaitè et al., 2000; Pruskus, 2005). Very often this value concept is identified with a certain ideal which might be followed and reached. According to Jovaiša (2003), value is the experience of an individual, which orients his/her thinking and feelings towards the highest objective goodness. The author stresses the positive nature of the value concept and its relationship to personality development. For many authors (Kuzmickas, 2001; Nind M., Rix J., Sheery K, 2005; Vasiliauskas, 2005) values are the goodness which meet human needs, desires, wishes and beliefs. Vasiliauskas (2005) states that this goodness (e.g. culture, science, technology, arts), is the objective peculiarity of values created by man, which satisfy our needs. This researcher also states that a person chooses to live such a life which s/he values, giving priority to particular objects and ways of life, accepting some of them and rejecting the others. The aim of education is to transform these goodnesses into values and make them the essential motive of the activities and human behaviour (Vasiliauskas, 2005, p. 10)

Similarly, the value concept is defined by Kuzmickas (2001, p.60) who states that the value is not a real fact, but it is what it has to be. That is why it is closely related to ideals and principles. Whereas principles are the most general form of human convictions. In this author's view, the belief in man, the respect for the individuality is a universal principle. Values are the essence of rules, which say what you can do, or what you cannot. It is the expression of what is good and what is bad, what is right and what is not Kuzmickas (2001, p.60). It is evident that each individual has his/her subjective understanding of what is good and what is bad, different from others.

Aramavičiūte (2005) stresses the role of convictions in values. The interest in some aspects of life (e.g. a school subject, friends, books) can overgrow into a firm conviction, desire to act according to one's reference or value point. This way a student learns to act, to behave, to live according to one's values, forming a definite behaviour of the definite organisational culture. 
The analysis of different academic sources has shown that different authors differently classify values. From the philosophical perspective there are fundamental values (love, goodness, beauty, truth) are most often analysed. They are considered to be compulsory for everybody to develop. Besides, based on these there are common humanistic, society and personal values (Jucevicienè, 1996; McLaughlin, 1997; Jucevičienè, Poškienè, Kudirkaitè et al., 2000).

Jucevičienè (2000), states, that there exists the relationship between fundamental and personal values which manifests in a human character and its main features (justice, honesty and respectfulness). She calls them as common humanistic values, the importance of which is different to different people.

McLaughlin (1997) stresses the importance of society and personal values, he states that society values are considered to be fundamental ones, they help people to live in a democratic and justice society and strive for their well-being and prosperity. Quite often these values as fundamental principles (freedom of speech, justice, personal autonomy and individual freedom) are embodied in the national state legal system and laws. Personal values reflect the level of choice of values, on which one's life may be built, they may confirm with the values, ideals, convictions of certain groups or organisations (McLaughlin, 1997; Jucevičienè, Poškienè, Kudirkaitè et al., 2000).

The value system is the fundamental of every individual and organisation. The investigation and evaluation of the value system is important for a deeper understanding of the ongoing processes characterizing the behaviour of individuals at different levels: organisation and society. Tolerance, respect for diversity are manifest and highly valued in a liberal and democratic society, in which school is one of the most important state institutions (McLaughlin, 1997).

So the school as educational institution is faced with a very complicated task. It has to develop such a set of values, which will coinside with the society values on the one hand, and will not violate personal values on the other hand (Senge, Cambron-McCabe, Lucas, 2000, Pruskus, 2005). According to Kasiulis and Barvydienè (2003, p.109) in different school organisational cultures there can be a different value system with a different set of values, which can have different degree of importance and manifestation, but all of them definitely have the influence on the culture of schooling.

\section{Research findings and discussion}

Organisational culture of each organisation has a whole complex of values which make influence on the way the school implements its objectives and resolves the problems faced in everyday life. A system of values that the school has is the foundation of its culture. The conducted empirical research was aimed at clarification which of the school values get the approval of teachers, which of them they think are important for school development.

The analysis of data has shown that respondent teachers think that common humanistic values are the most important in general. Particularly the following common humanistic values: justice (100\%), respect to people $(100 \%)$, kindness $(91 \%)$, honesty $(91 \%)$ and dutifulness $(91 \%)$ were considered by teachers to be the most important. Both the support and attention to the other were marked as having less importance $(68 \%)$.

The analysis of teacher data has also shown that some of the society values, namely responsibility $(100 \%)$ and tolerance $(96 \%)$ were considered by teachers as the most important, whereas,

freedom (81\%) and equality $(64 \%)$ as less important.

In the research teachers of the investigated schools had also to evaluate the organisational values of the school as a learning organisation. As the most important there were marked the following values: continuous learning and improvement (91\%), fostering of cultural values of the mankind (73\%), and critical thinking (68\%) and absence of conflicts (68\%) were less important.

The students, who participated in the research $(\mathrm{N}=160)$ were given to evaluate the same list of values belonging to to the same three groups: common humanistic, society and organisational values.

According to students, who participated in our research, there are the following common humanistic values that the majority of respondents considered to be the most important: respect to people (79/\%), kindness $(77 \%)$, justice $(76 \%)$, dutifulness $(74 \%)$, honesty $(73 \%)$.

As to the importance of the society values, the majority of respondent students marked the following: freedom $(73 \%)$, responsibility $(68 \%)$, tolerance $(67 \%)$ and equality $(67 \%)$.

According to student understanding and evaluation of the organisational values of the school as a learning organisation are less important. Only 60 per cent of students think that constant learning and improvement as well as fostering of cultural values of the mankind are important.

\subsection{The discussion of research results}

The comparison of the teacher and student results in separate schools, which have participated in the research, have not shown any statistically significant difference. This may have the following explanations. Firstly, the limitations of the study, the attitudes of only 4 schools were analyzed. Secondly, the similarity of results (of different schools can be explained by the fact that Lithuanian educational 
system is a centralized one. That means that all school organisations have to develop the values that are prescribed and recommended for schools to develop in the legal documents of the national level. This inevitably leads to an axiological unification of school organisations and to similarity of the developed organisational cultures.

The comparative data analysis of teacher and student subsamples have not shown any significant difference in attitudes towards values as well. We may presume that the investigated schools have already formed a strong organisational culture. It also shows that the process of value sharing promoting the development of homogeneous school cultures is under way.

\section{Conclusions}

1. Theoretical analysis of the value aspect of school culture has shown that values play the most important role in school organisational culture. It is based on the system of fundamental values which includes common humanistic values, society values and the organisational values, which are acknowledged by majority of organisation members and make influence on the development of their personal values concurrent with the values of the school organisation.

2. The conducted empirical research has shown that all four investigated Lithuanian schools are developing a homogeneous organisational culture. The attitudes of majority of teachers and students acknowledge the importance of all surveyed values: common humanistic values (justice, respect to people, kindness and responsibility), democratic society values (equality, freedom, tolerance, dutifulness) and the values of school as a learning organisation (continuous learning and improvement, fostering of cultural values of the mankind, critical thinking).

3. The stated hypothesis that most members (teachers and students) of the school culture will mark the common humanistic values as the most important in their school organisation cultures was proved. There were no statistically significant differences found.

4. The comparative analysis of teacher and student views provides evidence, that teacher attitudes and student attitudes towards a value system of their school organisational culture do not confront, they have similarities. This creates favourable conditions in investigated schools for the achievement of common organisational objectives, promotes the culture of value sharing and develops the cooperative culture and friendly relationship. The more members of the same organisation are committed to the same values and acknowledge them, the stronger is the organisational culture of their school.

\section{References}

Aramavičiūtė V. (2005). Vertybès kaip gyvenimo prasmès pamatas. Acta Paedagogica Vilnensia, 14, p. $18-27$.

Coleman M., Earley P. (2005). Leadership and management in education: cultures, change and context. Oxford: University Press.

Hofstede G. (1997). Cultures and Organizations: software of the mind. New York: McGRAW-HILL.

Hofstede G. (2001). Culture's consequences: comparing values, behaviors, institutions and organizations across nations. Thousand Oaks: Sage.

Jovaiša L. (2002). Edukologijos ivadas. Vilnius, Vilniaus universiteto leidykla.

Jucevičienė P., Poškienė A., Kudirkaitė L. ir kt. (2000). Universiteto kultūra ir jos tyrimas. Kaunas: Technologija.

Kasiulis J., Barvydienè V. (2003). Vadovavimo psichologija. Kaunas: Technologija.

Kavolis V. (1996). Kultūros dirbtuvé. Vilnius: Baltos lankos.

Kuzmickas B. (2001). Laimé, asmenybè, vertybès. Vilnius, Lietuvos teisès universiteto Leidybos centras.

McLaughlin T. H. (1997). Šiuolaikinè ugdymo filosofija: demokratiškumas, vertybès, ivvairovè. Kaunas: Technologija.

Nind M., Rix J., Sheery K. ir kt. (2005). Curriculum and pedagogy in inclusive education: values into practice. London: RoutledgeFalmer.

Poškienė A. (1998). Universiteto organizacijos kultūra - kompleksinis aukštojo mokslo edukacinis veiksnys. Daktaro disertacijos santrauka. Kaunas.

Palidauskaitè J. (2001). Viešojo administravimo etika. Kaunas: Technologija.

Pruskus V. (2005). Vertybès rinkoje: saveika ir pasirinkimas. Vilnius, VPU leidykla.

Robbins S. P. (2006). Organizacinès elgsenos pagrindai. Kaunas: Poligrafija ir informatika.

Schein, E. H. (1992). Organizational culture and leadership (2nd ed). San Francisco: Jossey-Bass.

Senge P., Cambron-McCabe N., Lucas T. ir kt. (2000). Schools that learn: a fifth discipline fieldbook for educators, parents and everyone who cares about education. New York: A currency book.

Simonaitienè B. (2007). Mokyklos - besimokančios organizacijos vystymas. Kaunas: Technologija.

Vasiliauskas R. (2005). Ugdymas ir vertybės. Acta Paedagogica Vilnensia, 14, p. 8-16. 